\title{
Genome-Wide Transcriptional Profiling of Ependymoma: Insight to Prognostic Indicators
}

\section{Abstract}

Pediatric ependymomas are characterized by unpredictable biological behavior and prognosis. The purpose of this study is to identify genes that are selectively expressed in WHO grade III ependymomas, relative to grade II ependymomas. We hypothesize that these genes play a role in their biologic progression and may help in predicting their clinical behavior. Paraffin-embedded tissue from three grade II and three grade III ependymomas were isolated by Laser Capture Micro-dissection. RNA was extracted, amplified and hybridized to Affymetrix Human X3P GeneChip Arrays containing probe sets that define 47,000 human genes. Statistical t-test and z-score analysis of differentially expressed genes was performed to identify groups of functionally related genes. Genome-wide transcriptional profiling and z-score analysis revealed increased expression in a set of genes involved in DNA damage repair, mitosis and cell cycle control in grade III, relative to grade II ependymomas. These genes included components of the G2M DNA damage checkpoint (e.g. CDC2 and cyclin B1 (CCNB1)) and the mitotic spindle checkpoint (e.g., BUB1 and securin (PTTG1)), kinetochore and centromere associated proteins (e.g. survivin (BIRC5)), and other genes recently identified in oncogenic signaling in glioblastoma (e.g. abnormal spindle-like microcephaly associated (ASP)). This study identifies subsets of genes highly expressed in grade III ependymomas compared to grade II ependymomas as potential prognostic indicators.

Keywords: Ependymoma; Prognostic indicators; Gene expression; Grade II ependymomas; Grade III ependymomas

Received: April 15, 2016; Accepted: May 03, 2016; Published: May 10, 2016

\section{Introduction}

Pediatric ependymomas are a heterogeneous group of neoplasms with clinical and biological behavior that is difficult to predict. Ependymomas represent the $3^{\text {rd }}$ most frequent intracranial brain tumor in children (after pilocytic astrocytomas and medulloblastomas), accounting for $6 \%$ to $12 \%$ of pediatric brain tumors [1]. Nonetheless, they are relatively rare and fewer than 150 cases are seen annually in the United States in children less than 19 years of age [2]. Despite advances in management and treatment, the prognosis of ependymomas remains poor. The five-year progression-free survival ranges between $30 \%$ and $60 \%$ with a poorer prognosis for those with residual disease after surgery, anaplastic histologic features or age younger than three years. Various investigators have reported that $80 \%-90 \%$ of ependymoma deaths were attributed to tumor progression at the primary site [3].

There is a lack of large prospective clinical trials aimed at better
Monica L Calicchio', Naren R Ramakrishna², Tucker Collins ${ }^{1,3}$, Keith L Ligon ${ }^{1,3-5}$ and Ali G Saad ${ }^{1,3,4}$

1 Department of Pathology, Children's Hospital Boston, Boston, USA

2 Radiation Oncology, Brigham and Women's Hospital, Boston, USA

3 Harvard Medical School, Boston, USA

4 Department of Pathology, Brigham and Women's Hospital, Boston, USA

5 Center for Molecular Oncologic Pathology, Dana-Farber Cancer Institute, Boston, USA

Corresponding author: Ali G Saad

झ ali.saad@bmcjax.com alisaad2007@hotmail.com

Department of Pathology, Baptist Health/ MD Anderson, Cancer Center and Wolfson Children's Hospital, Jacksonville, FL 32202, USA.

\section{Tel: 9042022966}

Citation: Calicchio ML, Ramakrishna NR, Collins T, et al. Genome-Wide Transcriptional Profiling of Ependymoma: Insight to Prognostic Indicators J Rare Dis Diagn Ther. 2016, 2:2.

defining reliable factors of prognostic significance. Retrospective studies addressing factors such as age, location, gender, extent of resection, and histologic grade as prognostic factors have yielded controversial results. Many authors have disputed the usefulness of grading ependymomas [3-8]. In virtually all studies, the extent of tumor resection (complete vs. incomplete) significantly influenced the clinical outcome [9-16]. However; in others, location appeared to represent the most important prognostic factor, regardless of the histologic grade $[15,16]$. Given this controversy, it appears that identifying markers that can predict the clinical behavior of ependymomas in the pediatric age group is necessary.

Ependymomas are central nervous system tumors that arise from the ependymal cells lining the cerebral ventricles and the central 
canal of the spinal cord [17-19]. Recent evidence suggests that ependymomas arise as a consequence of aberrant development in which the bulk of the malignant cells are maintained by a rare fraction of cancer stem cells [20]. These cancer stem cells are phenotypically similar to normal radial glial cells, but exhibit dysfunctional patterns of self-renewal and differentiation. Although about half of ependymomas appear karyotypically normal, a variety of chromosomal abnormalities have been detected in the tumors [21]. However, molecular studies analyzing the genetic alterations in ependymomas have failed to identify the clinically relevant genetic anomalies.

To expand existing information on the molecular features of ependymoma, we used Laser Capture Micro-dissection (LCM) to define and isolate small populations of ependymoma cells from both WHO grade II and grade III lesions. This allows us to efficiently enrich the "signal" from highly pure tumor cell areas and diminish "noise" generated by the bulk of the cells in a heterogeneous tumor. By comparing global patterns of gene expression in WHO grade II and grade III lesions from various anatomic locations, we sought to find genes preferentially expressed by all grade III lesions, relative to grade II lesions. For a subset of the genes, the data were confirmed on the protein level by immunoperoxidase analysis. This study identifies a module of related genes that are more highly expressed in grade III ependymomas, many of which interact to regulate the metaphase to anaphase transition. The findings support a possible mutator role for these genes in ependymoma development, suggesting that such tumors are driven in part by genomic instability associated with variant expression of kinetochore and centromere associated genes.

\section{Materials and Method}

\section{Selection of cases}

Formalin-fixed paraffin-embedded (FFPE) human tissue samples from newly diagnosed ependymomas ( 3 grades II and 3 grades III) were obtained from the files of the Department of Pathology at Boston Children's Hospital following an IRB-approved protocol. Cases were graded according to WHO criteria. Examples of grade II and grade III tumors are shown in Figures $1 \mathrm{~A}$ and $2 \mathrm{~A}$ respectively.

\section{RNA integrity assessment}

In an initial quality control step, FFPE tissues were screened for RNA quantity and quality using a quantitative real-time PCR assay with primers designed to two amplicons on the beta-actin gene, following the manufacturer's recommended protocol (Molecular Devices, Mountain View, CA). The $3^{\prime}$ amplicon is designed from a region roughly $100 \mathrm{nt}$ and the $5^{\prime}$ amplicon roughly 400nt from the poly A tail, respectively. The assumption in this screen is that the $3^{\prime}$ amplicon represents an indication of RNA quantity and a ratio of $3^{\prime}: 5^{\prime}$ amplicons represents a qualitative indicator of transcript length and "transcribability". The sample represents the average status (i.e., length and "transcribability") of other RNA molecules in the same block. This assay was performed on an Mx3000p real time PCR thermal cycler (Stratagene, LaJolla, CA) using the Brilliant SYBR Green QPCR Master Mix (Stratagene). Dilutions of Universal Human Reference RNA (Stratagene) are run from which a standard curve is used to

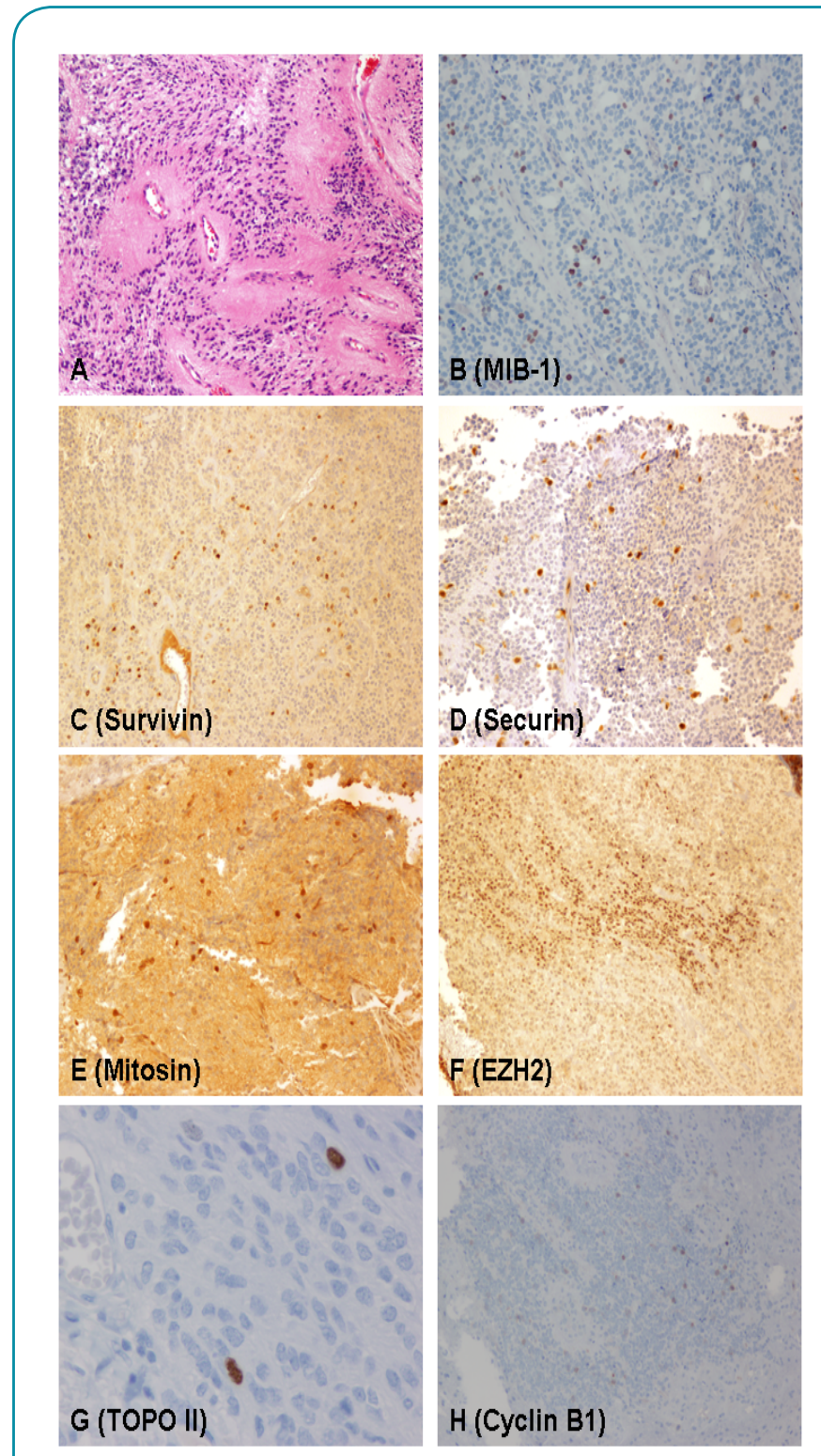

Figure 1

Validation of gene candidates by immunohistochemistry in a representative WHO Grade II ependymoma. From top, left panel to bottom, right panel are: (A) H\&E (B) Mib1 (C) TOPOII (D) EZH2 (E) Cyclin B1 (F) Securin (G) Mitosin $(\mathrm{H})$ Survivin.

estimate the amount of RNA in the sample. The assay measures the average beta-actin cDNA length by quantification of the PCR product yield from the $3^{\prime}$ end and compares this yield to a relatively $5^{\prime}$ sequence. The following primer sequences are used: 3' primers: HBAC1650: 5'-TCCCCCAACTTGAGATGTATGAAG-3', HBAC1717: 5'-AACTGGTCTCAAGTCAGTGTACAGG-3'; 5' primers: HBAC1355: 5'-ATCCCCCAAAGTTCACAATG-3' and HBAC1472: 5'-GTGGCTTTAGGATGGCAAG-3'. cDNA generated from the uRNA was serially diluted with poly I (Sigma-Aldrich, St. Louis, MO) and standard curves ( $\log$ uRNA amount vs. Ct) were generated for each of the primers sets. The standard curve consisted of four standards: $100 \mathrm{ng}, 10 \mathrm{ng}, 1 \mathrm{ng}$ and $0.1 \mathrm{ng}$. cDNA generated during the $1^{\text {st }}$ strand synthesis reaction served as the $100 \mathrm{ng}$ standard. 


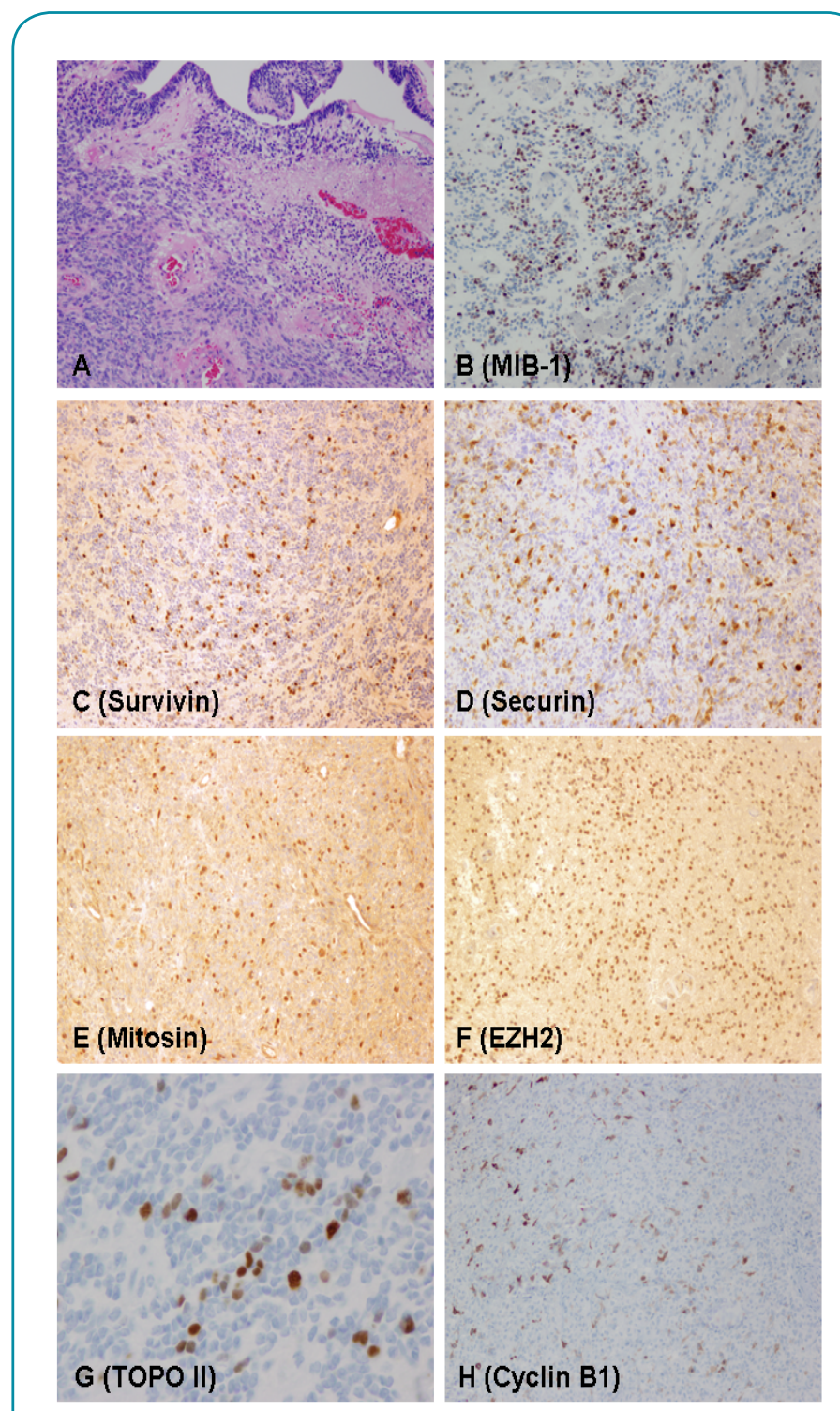

Figure 2

Validation of gene candidates by immunohistochemistry in a representative WHO Grade III ependymoma. From top, left panel to bottom, right panel are: (A) H\&E (B) Mib1 (C) TOPOII (D) EZH2 (E) Cyclin B1 (F) Securin (G) Mitosin (H) Survivin.

RNA quantity derived from the standard curve of the 3'primer set (HBAC1650, HBAC1717) was used to estimate the quantity of RNA in the sample. The ratio of the RNA yield obtained from both sets of PCR primers is the $3^{\prime} / 5^{\prime}$ ratio and was used as an indication of RNA quality. For example, if the cDNA contains both the $3^{\prime}$ and $5^{\prime}$ target sequences, the $3^{\prime} / 5^{\prime}$ ratio would be about 1 . Cross-linked or modified RNAs would have a ratio greater than 1. Based on this ratio, an estimation of the quality of RNA was made. RNAs yielding acceptable $3^{\prime}$ to $5^{\prime}$ ratios were selected for micro dissection.

\section{Laser capture micro-dissection}

Three WHO grade II and three WHO grade III ependymomas with useable RNA were identified in the quality control screen. Multiple FFPE sections were cut of the blocks containing lesional (c) Under License of Creative Commons Attribution 3.0 License tissue at $7 \mu \mathrm{m}$ thickness, deparaffinized, stained with toluidine blue and dehydrated following manufacturer's protocol (Paradise Reagent System Kit, Molecular Devices). Tumoral tissue was microdissected from PEN membrane glass slides using the UV cutting laser and IR capture laser on the Veritas Microdissection Instrument (Molecular Devices).

\section{RNA isolation, biotin-labeled cRNA transcription and microarray hybridization}

Following micro-dissection, RNA was extracted from the captured cells by incubating dissected tissue in the RNA extraction buffer (Paradise Reagent System Kit, Molecular Devices) overnight at 50 ㄷ. RNA isolation was performed following manufacturer's protocol using the MiraCol Purification Column as part of the Paradise Reagent System Kit and samples were eluted into $12 \mu \mathrm{l}$ elution buffer. RNA was amplified according to the manufacturer's suggested protocol (Paradise Reagent System Kit).

Samples were labeled with biotinylated probes using the Bioarray High Yield transcription kit following manufacturer's protocol (Enzo Biochemical, New York, NY). The concentration of the biotin-labeled CRNA was determined by UV absorbance utilizing a Bio-Tek UV Plate Reader (Bio-Tek Instruments, Winooski, VT). In all cases, $20 \mu \mathrm{g}$ of each biotinylated cRNA preparation was fragmented, assessed by gel electrophoresis and placed in a hybridization cocktail containing hybridization controls as recommended by the manufacturer. Samples were then hybridized to the Affymetrix Human X3P GeneChip Array at $45^{\circ} \mathrm{C}$ for $24 \mathrm{~h}$. Microarrays were washed and stained using the appropriate protocol for the Human X3P GeneChip Array on a Model 450 Fluidics station (www.affymetrix.com). The Fluidics station process is controlled by the Affymetrix GeneChip Operating Software (GCOS).

The Affymetrix Human X3P GeneChip Array is designed for wholegenome expression profiling of RNA from formalin-fixed paraffin embedded samples. The target sequences on the X3P Array are identical to those used for designing the Human Genome U133 Plus 2.0 GeneChip Array, for a total of 47,000 transcripts with 61,000 probe sets, although the probes on the two types of arrays are significantly different. The probe selection region on the X3P Array is restricted to the $300 \mathrm{bp}$ at the most $3^{\prime}$ end of the transcripts. In contrast, the standard Affymetrix design selects probe sets within the region 600 bases proximal to the $3^{\prime}$ ends (www.affymetrix.com). The GeneChip ${ }^{\circledR}$ X3P Array is used for whole-genome expression profiling of formalin-fixed, paraffinembedded samples.

\section{Data analysis and statistics}

Images from the scanned chips were processed using an Affymetrix Model 7000 scanner with autoloader (www.affymetrix.com). The Affymetrix GCOS v1.3 operating system (www.affymetrix.com) controls the Model 7000 scanner and data acquisition functions. Image files were downloaded, imported and analyzed using the GeneSifter Analysis Edition (www.genesifter.net). Statistical t-test analysis was performed in which a pairwise comparison was made between the ependymoma, WHO grade II vs. ependymoma, WHO grade III. Data was normalized to the mean. Results were 
filtered more stringently by imposing a threshold cut-off of 3.0 or greater fold-change in expression and a quality call of $1(P)$ in all replicates of at least one group. GeneSifter uses Gene Ontology (GO) reports and z-scores to summarize the biological processes, molecular functions or cellular components, as well as the KEGG (Kyto Encyclopedia of Genes and Genomes) pathways [22] associated with a gene list. The z-score is calculated by subtracting the expected number of genes in a GO term meeting the criterion from the observed number of genes and dividing by the standard deviation of the observed number of genes [23]. Z-scores can then be used to identify GO terms that are significantly over or under represented in a gene list. To assess the variability in gene expression in the blocks of formalin fixed and paraffin embedded lesions, independent LCM procedures, RNA isolations and microarray hybridizations were completed from the grade II and grade III tumors and the results were compared. By plotting the relative intensities of each of the genes from both samples on the same graph, it is possible to directly compare the data (Figure S1). The Pearson regression analysis suggests that the procedure is reproducible.

\section{Immunohistochemistry on tumor sections}

FFPE tissue sections were mounted on microscope slides. Immunohistochemical staining was optimized using a Ventana Discovery XT automated immunohistochemistry slide processing platform following the manufacturer's instructions. Following the Closed Loop Assay Development (CLAD) protocol (Ventana Medical Systems, Tucson, AZ), antibodies were optimized using either the OmniMap DAB anti-Mouse (HRP) or anti-Rabbit (HRP) detection kit (Ventana Medical Systems). Antibodies used in the study are provided in the Online Data Supplement (Table S1). For each antibody, standard quality control procedures were undertaken to optimize antigen retrieval, primary antibody dilution, secondary antibody detection and other factors for both "signal and noise". Immunohistochemistry slides were evaluated by two neuropathologists (AGS and KLL). For each antibody, a labeling index (LI) was rendered by dividing the number of positive tumor cells by the total number of tumor cells. The area with the highest positive tumor cells was selected for this purpose. GraphPad software (GraphPad Software, San Diego, CA) was used to calculate the $p$ values.

\section{Results and Discussion}

By immunohistochemistry, MIB-1, survivin, mitosin, securin, $\mathrm{EZH} 2$, TOPOII and $\mathrm{Cdc} 2$ labeling indices were all higher in grade III ependymomas than in grade II ependymomas. This difference was statistically significant and validated microarray findings. $P$ values are presented in Table 1.

\section{Differentially expressed genes in ependymoma}

Pairwise analysis was used to identify differentially expressed genes in three WHO grade II ependymomas, relative to three WHO grade III ependymomas. This analysis combines a fold-change cutoff and comparison statistics to generate a list of differentially expressed genes. Utilizing this approach, 271 genes (84 upregulated and 187 down-regulated) show significant differential regulation, defined as having elevated ( $>3$ fold) or diminished $(<3$
Table 1 Validation of gene candidates by IHC and their corresponding P-value.

\begin{tabular}{|c|c|c|c|c|c|}
\hline Antibody & Tissue & Median \pm SE & Mean & Range & $P$-value \\
\hline \multirow{3}{*}{ MIB-1 (Ki67) } & Normal brain & 0 & 0 & 0 & \multirow{3}{*}{0.02} \\
\hline & Grade II & $7 \pm 2.5$ & 8.1 & $1-25$ & \\
\hline & Grade III & $15 \pm 1.1$ & 15.4 & $11-20$ & \\
\hline \multirow{3}{*}{ Survivin } & Normal brain & 0 & 0 & 0 & \multirow{3}{*}{0.04} \\
\hline & Grade II & $3 \pm 0.7$ & 3.3 & $1-8$ & \\
\hline & Grade III & $11 \pm 2.5$ & 9.7 & $2-20$ & \\
\hline \multirow{3}{*}{ Mitosin } & Normal brain & 0 & 0 & 0 & \multirow{3}{*}{0.008} \\
\hline & Grade II & $2 \pm 0.4$ & 2.2 & $1-5$ & \\
\hline & Grade III & $10 \pm 2.4$ & 12 & $5-25$ & \\
\hline \multirow{3}{*}{ Securin } & Normal brain & 0 & 0 & 0 & \multirow{3}{*}{0.03} \\
\hline & Grade II & $2 \pm 0.6$ & 2.7 & $1-7$ & \\
\hline & Grade III & $10 \pm 2.4$ & 9.5 & $3-20$ & \\
\hline \multirow{3}{*}{ EZH2 } & Normal brain & 0 & 0 & 0 & \multirow{3}{*}{0.04} \\
\hline & Grade II & $7 \pm 2.9$ & 10.8 & $3-27$ & \\
\hline & Grade III & $25 \pm 5.1$ & 24.8 & $9-40$ & \\
\hline \multirow{3}{*}{ CyclinB1 } & Normal brain & 0 & 0 & 0 & \multirow{3}{*}{0.052} \\
\hline & Grade II & $1 \pm 0.4$ & 1.3 & $0-4$ & \\
\hline & Grade III & $3 \pm 0.8$ & 3.5 & $0-7$ & \\
\hline \multirow{3}{*}{ TOPOII } & Normal brain & $0 \pm 1$ & 1 & $0-3$ & \multirow{3}{*}{0.024} \\
\hline & Grade II & $3 \pm 0.6$ & 3 & $1-7$ & \\
\hline & Grade III & $9 \pm 1.7$ & 8.1 & 3-15 & \\
\hline \multirow{3}{*}{ Cdc2 } & Normal brain & $20 \pm 4.4$ & 21.6 & $15-30$ & \multirow{3}{*}{0.03} \\
\hline & Grade II & $3 \pm 4.6$ & 7.8 & $1-45$ & \\
\hline & Grade III & $20 \pm 8$ & 28.3 & $10-65$ & \\
\hline
\end{tabular}

fold) expression in the WHO grade III tumors relative to grade II tumors. Consider Table S2 for the complete list of differentially expressed genes. By calculating z-scores, it is possible to obtain gene ontology listings for biological process, molecular function and cellular component. These ontology listings depict genes that are either over- or under-represented in the overall list of differentially expressed genes (z-score greater than 2 or less than -2 , respectively) [23]. The $z$-score analysis of the biological process categories of differentially expressed genes was striking and revealed a collection of 19 Biological Process Gene Ontology (GO) groups involved in mitosis and the DNA replication checkpoint (Table 2). Similarly, nine statistically significant Cellular Component GO groups focused on the pericentric region of the chromosome and the kinetochore (Table 2). The set of genes contained within these GO groups overlap and form a module of genes involved in mitotic cell division and cellular proliferation (Table 3 ). The focuses of our study were genes within this module of mitosis/ cell cycle that had increased expression in grade III ependymoma.

\section{Cell proliferation}

Grade III ependymomas selectively express genes involved in cellular proliferation. Not unexpectedly, grade III ependymomas express the gene for the antigen identified by the monoclonal antibody Ki67 (MKI67) (Table 3 and Figures 1B and 2B). Expression of this gene is increased 3.84 fold in grade III tumors, relative to levels found in the grade II tumors (Figure 3 ). This finding is consistent with reports by many others and helps to validate the gene expression analysis from LCM samples of formalin fixed tissue. Expression of thymidylate synthase (TYMS), an enzyme that is key 
Table 2 Interesting gene ontologies by z-score.

\begin{tabular}{|l|c|l|c|}
\hline Biological Process GO group & Z-score & Cellular Component GO group & Z-score \\
\hline mitosis & 13.64 & chromosome, peri-centric region & 14.1 \\
\hline M phase of mitotic cell cycle & 13.54 & outer kinetochore of condensed chromosome & 10.43 \\
\hline chromosome segregation & 11.34 & DNA topoisomerase complex (ATP-hydrolyzing) & 7.09 \\
\hline spindle checkpoint & 9.83 & condensed chromosome kinetochore & 7.98 \\
\hline Chromosome condensation & 9.48 & spindle & 6.57 \\
\hline Cytokinesis mitosis & 8.82 & midbody & 6.19 \\
\hline mitotic chromosome condensation & 8.79 & kinetochore \\
\hline cell cycle & 8.29 & condensin complex \\
\hline mitotic sister chromatid segregation & 8.19 & spindle midzone \\
\hline mitotic checkpoint & 7.71 & \\
\hline establishment of chromosome localization & 7.01 & \\
\hline establishment of spindle localization & 6.15 & \\
\hline mitotic spindle elongation & 6.15 & \\
\hline regulation of exit from mitosis & 5.29 & \\
\hline apoptotic chromosome condensation & 4.96 & \\
\hline kinetochore assembly & 4.96 & \\
\hline G2/M transition of mitotic cell cycle & 4.55 & \\
\hline DNA replication checkpoint & 3.74 & \\
\hline G2/M transition DNA damage checkpoint & 3.37 & \\
\hline
\end{tabular}

Table 3 Genes involved in mitotic cell division and cellular proliferation.

\begin{tabular}{|c|c|c|c|c|c|c|c|}
\hline Gene Symbol & Gene Description & Cluster ID & Grade II & SEM & Grade III & SEM & Fold change \\
\hline BUB1 & $\begin{array}{l}\text { Budding uninhibited by benzimidazoles } 1 \\
\text { homolog }\end{array}$ & Hs.469649 & 0.0474 & $+/-0.0206$ & 0.3536 & $+/-0.0183$ & +7.46 \\
\hline SGOL1 & Shugoshin-like 1 & Hs.105153 & 0.0389 & $+/-0.0232$ & 0.2874 & $+/-0.0291$ & +7.39 \\
\hline CDC2 & Cell division cycle $2, \mathrm{G} 1$ to $\mathrm{S}$ and $\mathrm{G} 2$ to $\mathrm{M}$ & Hs.334562 & 1.6157 & $+/-0.2020$ & 11.1596 & $+/-1.2407$ & +6.91 \\
\hline KNTC2 & Kinetochore associated 2 & Hs.414407 & 0.1563 & $+/-0.0323$ & 0.937 & $+/-0.2451$ & +5.99 \\
\hline KIF14 & Kinesin family member 14 & Hs.3104 & 0.1688 & $+/-0.0919$ & 1.0099 & $+/-0.1489$ & +5.98 \\
\hline CCNB1 & Cyclin B1 & Hs.23960 & 0.3204 & $+/-0.0579$ & 1.7126 & $+/-0.4269$ & +5.35 \\
\hline CCNB2 & Cyclin B2 & Hs.194698 & 0.965 & $+/-0.3774$ & 3.7888 & $+/-0.3885$ & +3.93 \\
\hline PBK & PDZ binding protein & Hs.104741 & 0.1609 & $+/-0.0246$ & 0.8565 & $+/-0.1756$ & +5.32 \\
\hline CENPA & Centromere protein $\mathrm{A}$ & Hs.1594 & 0.1218 & $+/-0.0262$ & 0.6306 & $+/-0.0512$ & +5.18 \\
\hline CEP55 & Centrosomal protein $55 \mathrm{kDa}$ & Hs.14559 & 0.164 & $+/-0.0269$ & 0.8381 & $+/-0.0888$ & +5.11 \\
\hline ASPM & $\begin{array}{l}\text { Abnormal spindle-like microcephaly } \\
\text { associated }\end{array}$ & Hs.104741 & 0.1035 & $+/-0084$ & 0.5283 & $+/-0.0750$ & +5.10 \\
\hline ZWINT & ZW10 interactor & Hs.591363 & 1.9926 & $+/-0.3575$ & 9.8301 & $+/-0.9727$ & +4.93 \\
\hline TYMS & Thymidylate synthetase & Hs.592338 & 1.5112 & $+/-0.3952$ & 7.0513 & $+/-0.7508$ & +4.67 \\
\hline CENPF & Centromere protein $\mathrm{F}, 350 / 400 \mathrm{ka}$ & Hs.497741 & 1.0762 & $+/-0.1126$ & 4.8477 & $+/-0.8647$ & +4.50 \\
\hline PRC1 & Protein regulator of cytokinesis 1 & Hs.567385 & 1.7588 & $+/-0.2101$ & 7.7424 & $+/-1.6503$ & +4.40 \\
\hline IL1B & Interleukin 1 , beta & Hs.126256 & 0.1758 & $+/-0.0514$ & 0.7302 & $+/-0.0891$ & +4.15 \\
\hline CDKN3 & Cyclin-dependent kinase inhibitor 3 & Hs. 84113 & 0.2333 & $+/-0.0299$ & 0.9527 & $+/-0.2537$ & +4.08 \\
\hline NUSAP1 & Nucleolus and spindle associated protein 1 & Hs.615092 & 3.1304 & $+/-0.7955$ & 12.4848 & $+/-1.5184$ & +3.99 \\
\hline ANLN & Anillin, actin binding protein & Hs.62180 & 0.4846 & $+/-0.0192$ & 1.9148 & $+/-0.3799$ & +3.95 \\
\hline SPBC25 & Spindle pole body component 25 homolog & Hs.421956 & 0.1178 & $+/-0.0400$ & 0.4645 & $+/-0.1049$ & +3.94 \\
\hline SMC4 & Structural maintenance of chromosomes 4 & Hs.58992 & 1.7954 & $+/-0.2603$ & 7.0696 & $+/-0.8005$ & +3.94 \\
\hline CENPN & Centromere protein $\mathrm{N}$ & Hs.55028 & 0.1288 & $+/-0.0463$ & 0.5031 & $+/-0.1198$ & +3.91 \\
\hline ORC1L & Origin recognition complex, subunit 1-like & Hs.17908 & 0.063 & $+/-0.0292$ & 0.2446 & $+/-0.0306$ & +3.88 \\
\hline ORC1L & Origin recognition complex, subunit 1-like & Hs.17908 & 0.0916 & $+/-0.0209$ & 0.3179 & $+/-0.0393$ & +3.47 \\
\hline MKI67 & Ki-67 & Hs.80976 & 0.1976 & $+/-0.0712$ & 0.7592 & $+/-0.1441$ & +3.84 \\
\hline CDCKN2C & Cyclin-dependent kinase inhibitor $2 \mathrm{C}$ & Hs.525324 & 1.0801 & $+/-0.7249$ & 4.0869 & $+/-0.3091$ & +3.78 \\
\hline NUF2 & $\begin{array}{l}\text { NUF2, NDC80 kinetochore complex } \\
\text { component, homolog }\end{array}$ & Hs.651950 & 0.159 & $+/-0.0350$ & 0.6003 & $+/-0.1017$ & +3.78 \\
\hline TOP2A & Topisomerase (DNA) II alpha $170 \mathrm{kDa}$ & Hs.156346 & 0.5733 & $+/-0.2563$ & 2.1615 & $+/-0.0933$ & +3.77 \\
\hline
\end{tabular}




\begin{tabular}{|c|c|c|c|c|c|c|c|}
\hline NCAPH & Non-SMC condensin I complex, subunit H & Hs.308045 & 0.2752 & $+/-0.0630$ & 1.0333 & $+/-0.1329$ & +3.75 \\
\hline NCAPG & Non-SMC condensin I complex, subunit G & Hs.567567 & 0.4423 & $+/-0.1776$ & 1.6327 & $+/-0.1173$ & +3.69 \\
\hline BIRC5 & $\begin{array}{l}\text { Baculoviral IAP repeat-containing } 5 \\
\text { (survivin) }\end{array}$ & Hs. 514527 & 0.4676 & $+/-0.0641$ & 1.6384 & $+/-0.2738$ & +3.50 \\
\hline MKI67 & Ki-67 & Hs.80976 & 1.0415 & $+/-0.5172$ & 4.1638 & $+/-0.3932$ & +3.40 \\
\hline CKS2 & CDC28 protein kinase regulatory subunit 2 & Hs.83758 & 1.3003 & $+/-0.0721$ & 4.4016 & $+/-0.8936$ & +3.39 \\
\hline CENPM & Centromere protein $\mathrm{M}$ & Hs.208912 & 0.2569 & $+/-0.0225$ & 0.852 & $+/-0.1905$ & +3.32 \\
\hline BIRC5 & $\begin{array}{l}\text { Baculoviral IAP repeat-containing } 5 \\
\text { (survivin) }\end{array}$ & Hs. 514527 & 0.1844 & $+/-0.0750$ & 0.6069 & $+/-0.0333$ & +3.29 \\
\hline PTTG1 & Pituitary tumor-transforming 1 & Hs.350966 & 3.315 & $+/-0.2738$ & 10.6963 & $+/-1.1197$ & +3.23 \\
\hline POLE2 & Polymerase (DNA directed), episilon 2 & Hs.162777 & 0.2915 & $+/-0.0282$ & 0.9535 & $+/-0.0191$ & +3.21 \\
\hline $\mathrm{EZH} 2$ & Enhancer of zeste homolog 2 & Hs.444082 & 1.1795 & $+/-0.2933$ & 3.7865 & $+/-0.7287$ & +3.21 \\
\hline $\mathrm{CDC} 25 \mathrm{~b}$ & Cell division cycle 25 homolog B & Hs.153752 & 6.263 & $+/-0.3384$ & 19.0309 & $+/-2.3736$ & +3.04 \\
\hline CDC45L & CDC45 cell division cycle 45 -like & Hs.474217 & 0.2088 & $+/-0.0517$ & 0.6304 & $+/-0.1348$ & +3.02 \\
\hline \multicolumn{8}{|c|}{ Genes down regulated in grade III tumors } \\
\hline Gene Symbol & Gene Description & Cluster ID & Grade II & SEM & Grade III & SEM & Fold change \\
\hline DYNC1I1 & $\begin{array}{l}\text { Dynein, cytoplasmic } 1 \text {, intermediate chain } \\
1\end{array}$ & Hs.440364 & 3.9184 & $+/-0.5431$ & 0.1369 & $+/-0.0805$ & -28.62 \\
\hline VEGFC & Vascular endothelial growth factor C & Hs.435215 & 0.6955 & $+/-0.1632$ & 0.06 & $+/-0.0370$ & -11.59 \\
\hline TGFA & Transforming growth factor, alpha & Hs.170009 & 0.6327 & $+/-0.1606$ & 0.1027 & $+/-0.0589$ & -6.16 \\
\hline BTC & Betacellulin & Hs.591704 & 0.245 & $+/-0.0614$ & 0.0518 & $+/-0.0198$ & -4.73 \\
\hline LOH11CR2A & $\begin{array}{l}\text { Loss of heterozygosity, } 11 \text {, chromosomal } \\
\text { region } 1 \text {, gene } A\end{array}$ & Hs.152944 & 10.0959 & $+/-1.6467$ & 2.1902 & $+/-1.0865$ & -4.61 \\
\hline PPP3CA & Protein phosphatase 3 & Hs.435512 & 1.3463 & $+/-0.1937$ & 0.4198 & $+/-0.1367$ & -3.21 \\
\hline
\end{tabular}

for DNA replication and repair, is preferentially increased (4.67 fold) in grade III tumors (Table 3). Increased expression of thymidylate synthase may be an indication of resistance to 5-fluorouracil and be associated with poor prognosis in ependymomas, as it is in other types of cancer. Additionally, expression of topoisomerase II, which maintains the proper topology of chromatid DNA and is essential for chromosome segregation, is also increased in grade III ependymomas ( 3.77 fold) (Table 3 and Figures $\mathbf{1 G}$ and 2G). The origin recognition complex (ORC) is a conserved protein complex that is essential for the initiation of DNA replication. ORC1L is the largest subunit of this complex and levels of this protein vary during the cell cycle in a manner controlled by ubiquitinmediated proteolysis. Expression of ORC1L is increased 3.88 fold in grade III tumors (Table 3). Enhancer of zeste homolog 2 (EZH2) is a known repressor of transcription and has been shown to promote proliferation and invasion of prostate cancer cells [24]. Expression of EZH2 is increased 3.2 fold in grade II tumors (Table 3 and Figures 1F and 2F).

\section{G2M DNA damage checkpoint}

The G2/M DNA damage checkpoint serves to prevent the cell from entering mitosis if the genome is damaged. To this end, the activity of the cdc2-cyclin B complex plays a key role in regulating this transition. As cells approach $M$ phase, the phosphatase cdc25B is activated by phosphorylation, which in turn activates cdc2. In grade III ependymomas, levels of cdc2 (CDC2) and cyclin B1 (CCNB1) transcripts are increased 6.91 and 5.35 fold, respectively relative to grade II tumors (Table 3 and Figures $\mathbf{1 H}$ and $2 \mathrm{H}$ ). Similarly, expression of cdc25B (CDC25b) is increased 3.04 fold (Table 3 and Figure 4). Levels of the checkpoint kinases (CHK1 and CHK2), that phosphorylate and inactivate cdc25, are not changed in grade III tumors. The increased expression of $\mathrm{cdc} 25 \mathrm{~b}$ in ependymomas is consistent with the over expression of cdc25b seen in other malignancies, including gliomas, where multivariant analysis suggested that increased expression of cdc25 was an unfavorable prognostic factor [25]. However, over expression of cdc $25 \mathrm{~b}$ overrides radiation-induced G2-M arrest and results in increased apoptosis in other types of cancer cells [26].

\section{Mitotic spindle checkpoint}

The spindle checkpoint ensures faithful chromosome segregation by linking the onset of anaphase to the establishment of bipolar kinetochore-microtubule attachment. This checkpoint is a cell cycle surveillance mechanism that ensures the fidelity of chromosome segregation during mitosis. Our results showed increased expression of mitotic checkpoint components including Bub1 and ZWINT (Figures 5A and 5B). Bub1 (BUB1) directly inhibits the ubiquitin ligase activity of the anaphase promoting complex or cyclosome (APC/C) by phosphorylating its activator Cdc20. BUB1 depletion leads to the accumulation of misaligned chromatids in which both sister kinetochores are linked to microtubules in an abnormal manner [27]. Increased expression of BUB1 in grade III ependymomas could represent cellular compensation for defects in other molecular components of the mitotic spindle damage checkpoint and increased expression of BUB1 might be a marker of ependymomas with chromosomal instability. The expression of BUB1 is most dramatically ( 7.46 fold) increased in grade III relative to grade II ependymomas. ZWINT (Zwint 10 interactor) is a gene that is required for the mitotic check point signaling [28]. ZWINT interacts with Mis12 [29] which is required for kinetochore localization of ZW10. ZW10, in turn and its partner Rod are required for the recruitment of the motor protein dynein/dynactin to the kinetochore. Expression of Zwint 10 interactor was increased 4.93 fold in grade III ependymoma. 


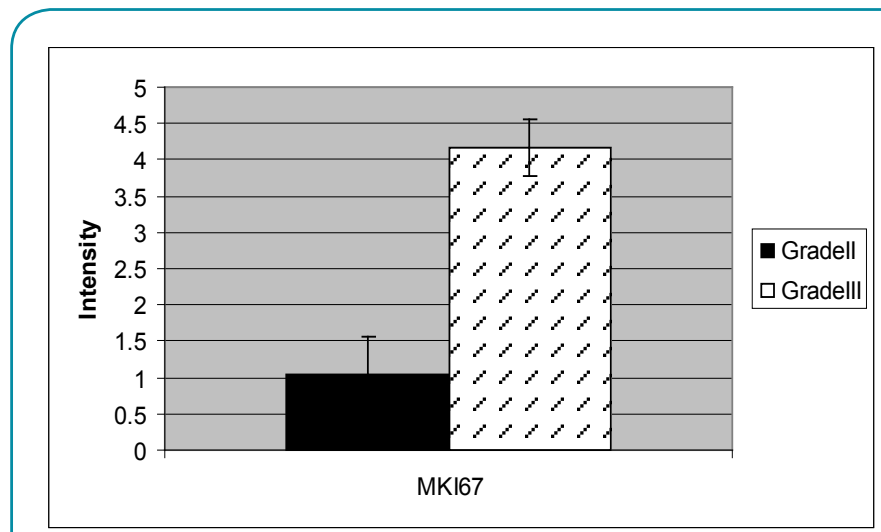

Figure 3 Increased expression of Ki-67 in WHO grade III ependymoma.

A

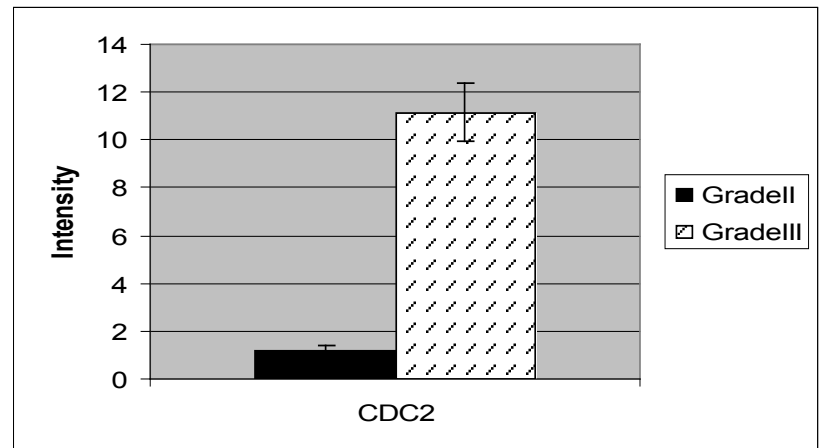

B

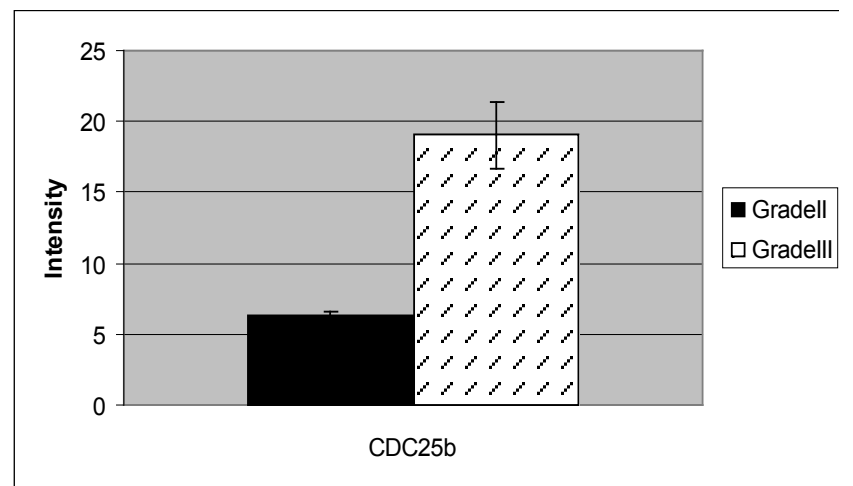

Figure 4

Increased expression of CDC2 and CDC25B in WHO grade III ependymoma.

Interestingly, levels of dynein were dramatically decreased in grade III ependymomas, relative to the less aggressive grade II tumors (Figure $\mathbf{5 C}$ ).

\section{Downstream effectors of the mitotic checkpoint}

The anaphase-promoting complex or cyclosome (APC/C) complex is the downstream effector of the mitotic checkpoint. Unattached kinetochores activate the BubR1/Mad3-dependent checkpoint pathway that inhibits Cdc20-mediated activation of the APC/C. When all the chromosomes align, the checkpoint ๑) Under License of Creative Commons Attribution 3.0 License
A

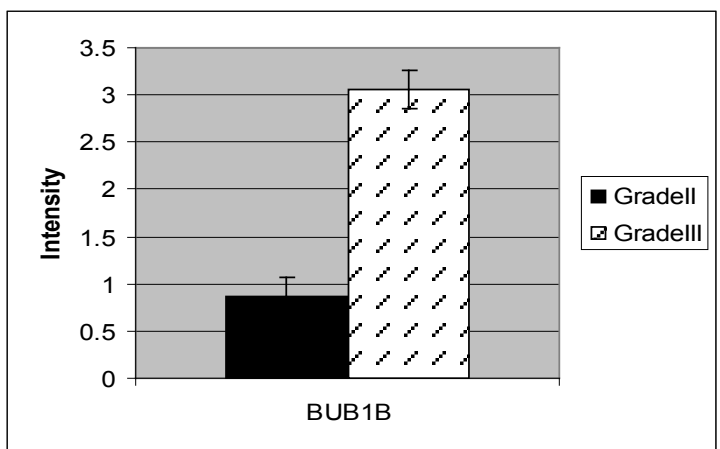

B

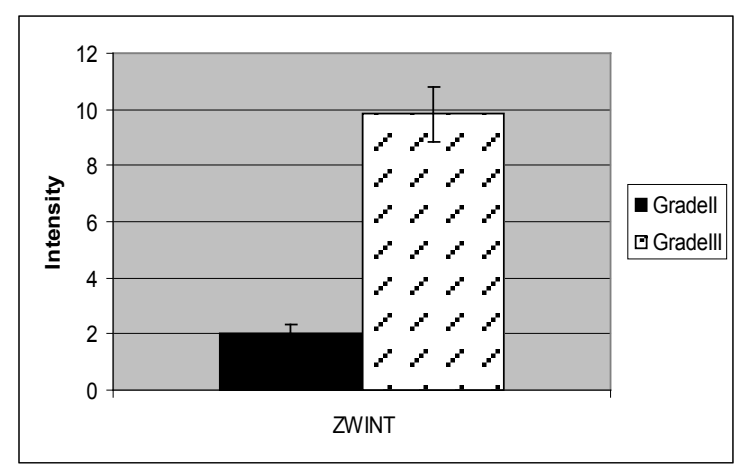

C

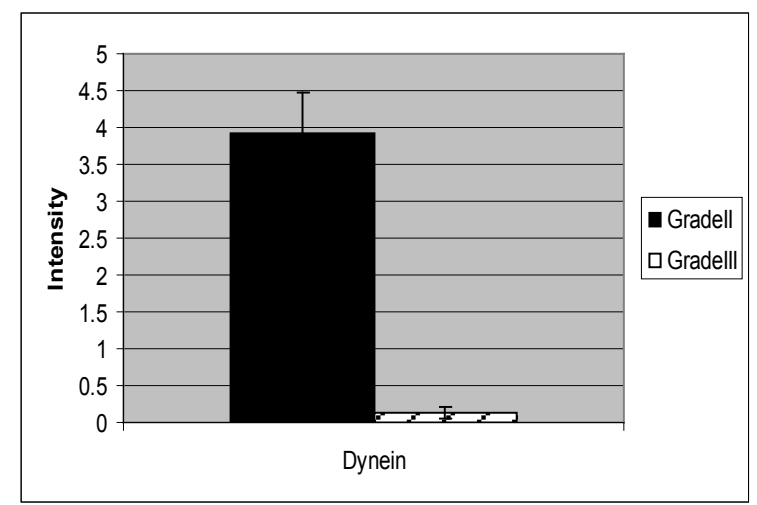

D

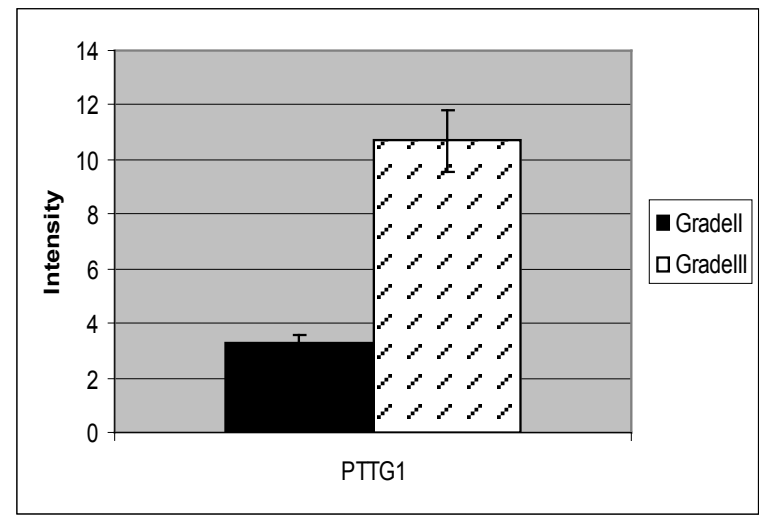

Figure 5

Differential expressions of mitotic checkpoint genes in ependymoma. 
signal is extinguished allowing Cdc20 to activate the APC/C complex. Securin, which was also identified as the pituitary tumor-transforming gene 1 (PTTG1) is a chromosome segregation regulator and an anaphase inhibitor that binds and inhibits separase. APC/C mediated ubiquitination of securin and cyclin B1 and subsequent degradation by the proteosome triggers anaphase entry. Separase then cleaves cohesin, allowing the sister chromatids to separate. Here we find that both securin (PTTG1) (Figures 1D, 2D and 5D) and cyclin B1 (CCNB1) expression are increased 3.23 and 5.35 fold, respectively, in grade III ependymomas. Notably, over- or under-expression of securin can give rise to mitotic catastrophe, possibly be driving chromosomal rearrangement [30].

\section{Kinetochore and centromere associated proteins (Figure 6)}

Kinetochore associated 2 (KNTC2, which is also known as Hec) is part of the Hec1/Ndc80 complex. Expression of KNTC2 is increased about 6 fold in grade III ependymomas. Additionally, a component of the $\mathrm{Hec} / \mathrm{Ndc} 80$ complex, NUF2, is increased 3.78 fold in the grade III ependymomas. Centromere protein $\mathrm{F}$ (CENP-F or mitosin) is a centromere-outer kinetochore protein. It localizes to the spindle midzone and the intracellular bridge in late anaphase and telophase, respectively and is subsequently degraded. Expression of CENP-F is increased 4.5 fold in grade III ependymomas (Figures $\mathbf{1 E}$ and $2 \mathrm{E}$ ). Centromere protein $A$ (CENP-A) encodes a centromere protein that contains a histone fold domain that is required for targeting to the centromere. CENP-A is proposed to be a component of a modified nucleosome-like structure in which it replaces one or both copies of conventional histone H3. Expression of CENP-A is increased 5.18 fold in grade III ependymomas. Shugoshin-like 1 (SGOL1) expression was increased 7.39 fold in grade III relative to grade II ependymomas. Survivin (BIRC5, or baculoviral IAP repeatcontaining 5) (Figures $\mathbf{1 C}$ and $\mathbf{2 C}$ ). At the onset of mitosis, survivin regulates microtubulule dynamics at inner kinetochores via the chromosomal passenger complex and mitotic spindle formation via an independent pool not associated with passenger proteins. In the chromosomal passenger complex, survivin interacts with the inner centromere protein (INCENP), Borealin/Dasra B and the mitotic kinase, Aurora $B$. These interactions are required to target the complex to kinetochores, correct misaligned chromosomes, properly form the central spindle and complete cytokinesis. During mitosis, survivin is a chromosomal passenger protein that localizes to kinetochores at metaphase, transfers to the central spindle midzone at anaphase and accumulates in midbodies at telophase. Disruption of survivin-microtubule interactions results in loss of survivin's anti-apoptosis function, a mechanism involved in cell death during mitosis. The overexpression of survivin in ependymomas may overcome this apoptosis checkpoint and favor aberrant progression of transformed cells through mitosis.

\section{Other genes whose products are associated with the regulation of mitosis (Figure 7)}

CEP55 is centrosomal in interphase cells and is lost from the centrosome during entry into mitosis. At anaphase, the protein accumulates diffusely at the spindle midzone and later appears

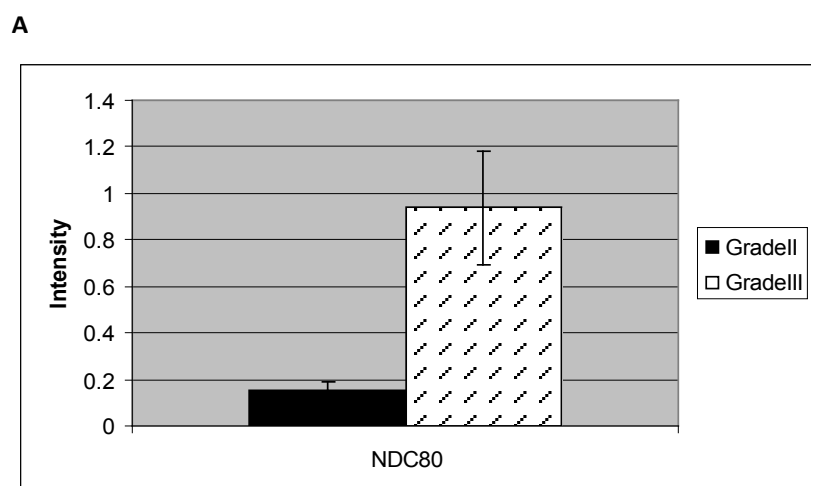

B

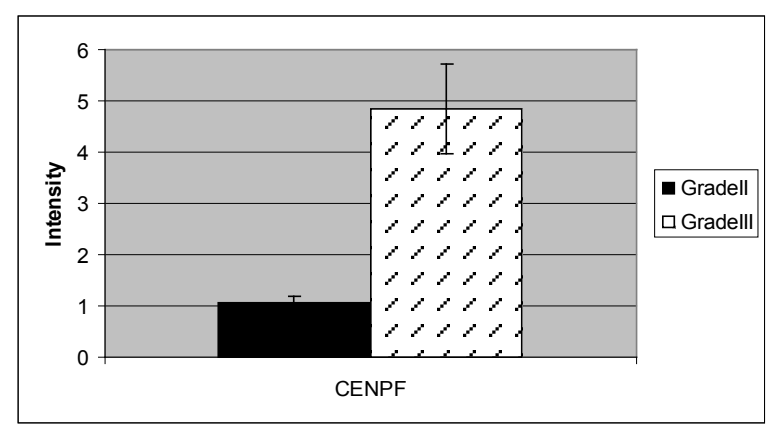

C

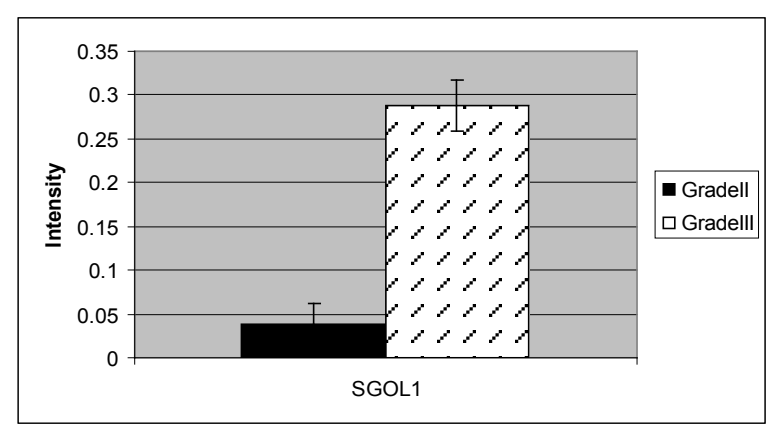

D

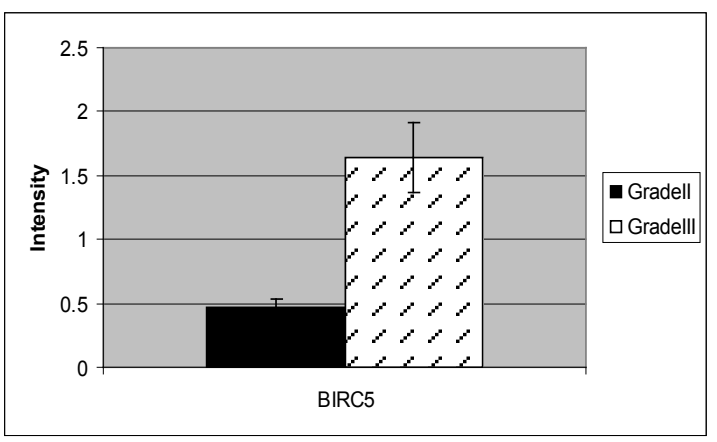

Figure 6 Increased expression of kinetochore and centromere associated proteins in grade III ependymoma.

at the midbody and plays a role in cytokinesis [31]. The 5.11 fold increased expression of CEP55 in ependymomas, suggests that the high level of expression of the protein in the tumor may impair its ability to relocate to the midbody and to function in mitotic exit and cytokinesis. Protein regulator of cytokinesis (PRC1) 
A

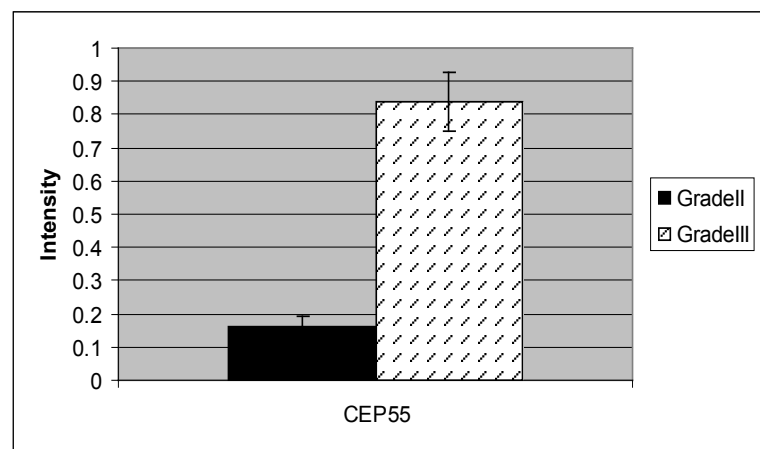

B

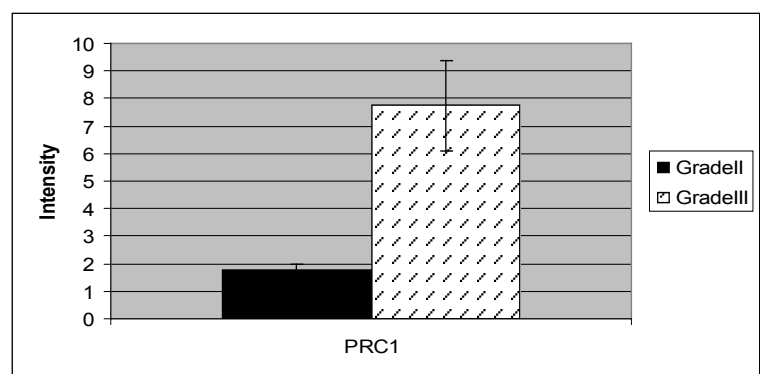

C

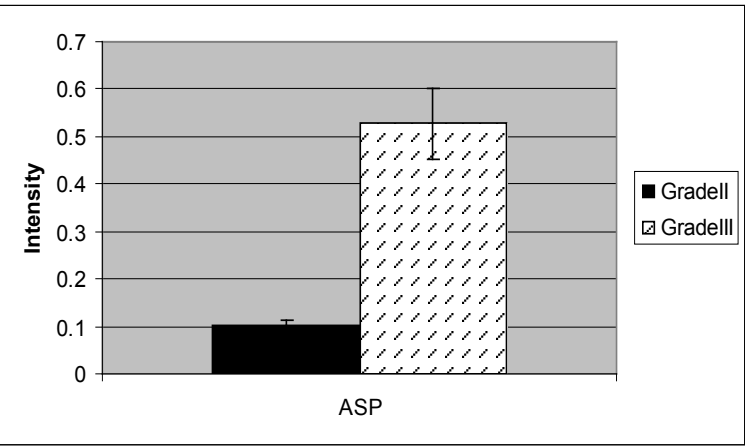

D

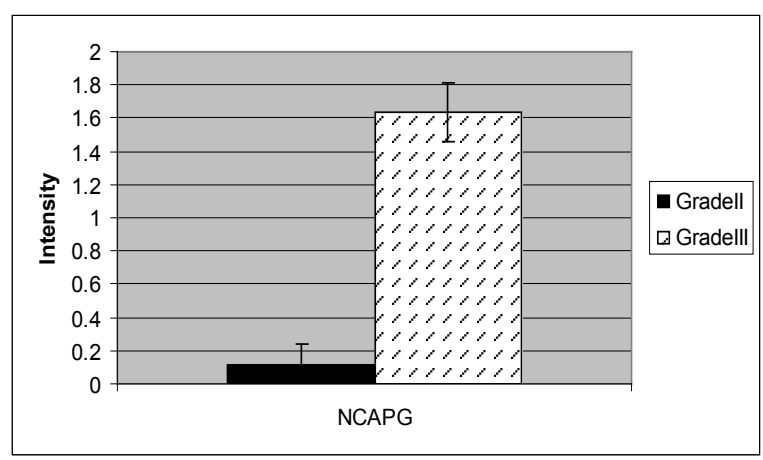

Figure 7

Increased expression of genes regulating mitosis in grade III ependymoma.

Expression of PRC1 in grade III ependymomas is increased 4.4 fold, relative to grade II tumors. Abnormal spindle-like microcephaly associated, ASP. Expression of ASP in grade III ependymomas is increased 5.10 fold, relative to grade II ependymomas. It is a critical regulator of brain size, likely through it role in promoting neuroblasts proliferation and symmetric division. ASP has recently been shown to be increased in expression in a glioblastomas [32]. Condensins are multi-subunit protein complexes that play a central role in mitotic chromosome assembly and segregation [33]. Vertebrate cells have two different condensin complexes, condensins I and II, each containing a unique set of regulatory subunits. Condensin I gains access to chromosomes only after the nuclear envelope breaks down and collaborates with condensin II to assemble metaphase chromosomes with fully resolved sister chromatids. Condensin II participates in an early state of chromosome condensation within the prophase nucleus. Structural maintenance of chromosomes (SMC) proteins are found in condensing complexes and are chromosomal ATPases that play fundamental roles in many aspects of higher-order chromosome organization and dynamics. In eukaryotes, SMC1 and SMC3 act as the core of the cohesin complex that mediate sister chromatid cohesion, whereas SMC2 and SMC4 function as the core of the condensin complexes that are essential for chromosome assembly and segregation. Expression of SMC4 in grade III ependymomas is increased 3.94 fold, in grade III relative to relative to grade II ependymoma. The SMC complexes form unique ring- or V-shaped structures with long coiled-coil arms, and function as ATP-modulated, dynamic molecular linkers of the genome [33, 34]. As with SMC4, expression of the condensin I regulatory components subunits $G$ and $H$ (NCAPG and NCAPH) is increased. Levels of NCAPG and NCAPH are increased about 3.7 fold in grade III ependymomas. Since condensins regulate proper assembly of centromeric heterochromatin and thereby contribute to the back-to-back orientation of sister kinetochores, altered expression of the condensin regulatory components may lead to abnormal interactions between kinetochores and microtubules. Similarly, since condensins play critical roles in the resolution of sister chromatids in metaphase, altered expression of these regulatory components in progressing ependymomas may lead to chromosomal alterations, such as the formation of chromosome bridges in the subsequent anaphase.

Recent work emphasizes the importance of identifying genomic data sets for gene co-expression modules that play a key role in tumor genesis. Here we utilize z-score analysis to identify a module of about 40 genes that consists of mitosis and cell cycle genes that are preferentially expressed in the grade III ependymoma. In previous studies to identify gene modules expressed in glioblastoma, a weighted gene expression network was constructed based on pairwise Pearson correlations between the expression profiles [32]. Unsupervised hierarchical clustering was used to detect modules of highly co-expressed genes. In that analysis, a mitosis/cell cycle gene expression module of 185 genes was identified in glioblastoma that was also present in breast cancer and significantly overlaps with the "metasignature" for undifferentiated cancer [32]. Of these genes, many are known to interact physically and/or functionally to regulate the metaphase to anaphase transition. There is significant overlap between the genes found in the ependymoma and the glioblastoma cell cycle/ mitosis modules. Notably, some of the most connected hub genes in the glioblastoma network were found in the ependymoma module (e.g., ASP, BUB1, CCNBP1, CDC2, EZH2, PTTG1, PRC1, and TOP2A). These results suggest that expression of these genes 
Table 4 Summary of genes in the discussion section along with their most important biological function.

\begin{tabular}{|c|c|c|c|}
\hline \multirow{2}{*}{ Marker } & \multirow{2}{*}{ Function } & \multicolumn{2}{|l|}{ Intensity } \\
\hline & & Grade II & Grade III \\
\hline MKI67 & $\begin{array}{l}\text { Cell proliferation: the protein is expressed during all active phases of the cell cycle but } \\
\text { absent from resting cells }\end{array}$ & 1.04 & 4.16 \\
\hline CDC2 & $\begin{array}{l}\text { Downstream effector of the mitotic checkpoint: role in G2M DNA damage checkpoint. } \\
\text { Serves to prevent the cell from entering mitosis if the genome is damaged. }\end{array}$ & 1.16 & 11.16 \\
\hline $\mathrm{CDC} 25 \mathrm{~b}$ & G2M DNA damage checkpoint: activated by phosphorylation and in turns activates CDC2. & 6.26 & 19.03 \\
\hline BUB1B & $\begin{array}{l}\text { Mitotic checkpoint component: a kinase that plays a key role in the assembly of the } \\
\text { kinetochore signaling complex. }\end{array}$ & 0.87 & 3.05 \\
\hline $\begin{array}{l}\text { ZWINT (Zwint } 10 \\
\text { interactor) }\end{array}$ & Mitotic spindle checkpoint: Required for mitotic checkpoint signaling. & 1.99 & 9.83 \\
\hline Dynein & $\begin{array}{l}\text { Mitotic checkpoint component: is a motor protein which converts the chemical Energy } \\
\text { contained in ATP into the mechanical energy of movement. }\end{array}$ & 3.92 & 0.14 \\
\hline PTTG1 (Securin) & $\begin{array}{l}\text { Downstream effector of the mitotic checkpoint: a chromosome segregation regulator and } \\
\text { an anaphase inhibitor that binds and inhibits separase. }\end{array}$ & 3.31 & 10.69 \\
\hline $\begin{array}{l}\text { NDC80 (Kinetochore } \\
\text { associated 2) }\end{array}$ & $\begin{array}{l}\text { Mitotic spindle checkpoint: Required to recruit a subset of checkpoint proteins to the } \\
\text { kinetochore. }\end{array}$ & 0.15 & 0.94 \\
\hline CENP-F (mitosin) & $\begin{array}{l}\text { Mitotic spindle checkpoint: in late } \mathrm{G} 2 \text {, it is recruited by Bub1 to the kinetochore and } \\
\text { maintains this association through early anaphase. }\end{array}$ & 1.07 & 4.85 \\
\hline $\begin{array}{l}\text { SGOL1 (Shugoshin- } \\
\text { like 1) }\end{array}$ & Mitotic spindle checkpoint: protects cohesion complexes at centromeres. & 0.04 & 0.28 \\
\hline CENP-A & $\begin{array}{l}\text { Mitotic spindle checkpoint: component of a modified nucleosome-like structure in which it } \\
\text { replaces one or both copies of conventional histone } \mathrm{H} 3 \text {. }\end{array}$ & 0.12 & 0.63 \\
\hline BIRC5 (survivin) & $\begin{array}{l}\text { Mitotic spindle checkpoint: expressed in the } \mathrm{G} 2 / \mathrm{M} \text { phase of the cell cycle in a cycle } \\
\text { regulated fashion. }\end{array}$ & 0.46 & 1.64 \\
\hline $\begin{array}{l}\text { CEP55 (centrosomal } \\
\text { protein 55) }\end{array}$ & $\begin{array}{l}\text { Regulation of mitosis: involved in centrosome-dependent cellular functions such as } \\
\text { centrosome duplication and/or cell cycle progression, or in the regulation of cytokinesis. }\end{array}$ & 0.16 & 0.84 \\
\hline $\begin{array}{l}\text { PRC1 (Protein regulator } \\
\text { of cytokinesis) }\end{array}$ & $\begin{array}{l}\text { Regulation of mitosis: expressed at high levels during } \mathrm{S} \text { and } \mathrm{G} 2 / \mathrm{M} \text { and drops after the Cells } \\
\text { exit mitosis and enter the } \mathrm{G} 1 \text { phase of the cell cycle. It becomes associated with mitotic } \\
\text { spindles during mitosis and localizes to the cell mid-body during cytokinesis. }\end{array}$ & 1.76 & 7.74 \\
\hline ASP & $\begin{array}{l}\text { Regulation of mitosis: the human ortholog of a Drosophila mitotic spindle protein which is } \\
\text { essential for normal mitotic spindle function in neuroblasts. }\end{array}$ & 0.1 & 0.53 \\
\hline $\begin{array}{l}\text { NCAP-G (Condensin } \\
\text { subunit G) }\end{array}$ & $\begin{array}{l}\text { Mitotic spindle checkpoint: altered expression may leads to chromosomal alterations such } \\
\text { as the formation of chromosomes bridges in the subsequent anaphase. }\end{array}$ & 0.44 & 1.63 \\
\hline
\end{tabular}

may be more predictive of clinical outcome than the traditional markers of proliferation. Additionally, the genes identified in the module may be up-regulated by key molecular lesions, such as BRAC1 in breast cancer, that confer a proliferative advantage, thus raising the possibility that therapies targeting this module may useful in patients with brain tumors. A summary of the results is presented in Tables $\mathbf{3}$ and $\mathbf{4}$.

Mitotic cells face the challenging task of linking kinetochores to shortening and lengthening microtubules and actively regulating these dynamic attachments to produce accurate chromosome segregation. The microtubule-binding interface of the kinetochore is of key importance in chromosome segregation.

It is tempting to speculate that aneuploidy plays a key role in ependymoma progression. The cells found in WHO grade II ependymomas appear to have a relatively normal complement of cell division proteins. In the transition from WHO grade II to grade III, the increased expression of a module of cell cycle and cell division genes could disrupt processes responsible for mitotic control and DNA maintenance. Additional chromosome breakage, structural rearrangements and duplication errors arise. These progressing tumor cells rapidly become aneuploid as a result of aberrant mitotic divisions. These changes result in the tumor cell proliferation and the atypical appearance of tumor cells found in the grade III ependymoma.

In summary, we demonstrated the existence of a panel of genes that are highly expressed in grade III ependymomas compared to grade II ependymomas. These genes may be useful in shedding light on the pathogenesis of ependymomas and their progression into higher grade. As the clinical behavior of ependymomas is 
still unpredictable, clinical identification of these genes may aid in diagnosis and prognosis. This is particularly true in a subset of ependymomas in which assigning a WHO grade is challenging, i.e., those ependymomas with focal necrosis, vascular proliferation, borderline increase in mitoses and atypical cytologic features that fall short of being anaplastic. This group of ependymomas often represents a diagnostic and management problems for pathologists and neuro-oncologists, respectively. Identification of a panel of immunostains that can identify this group of ependymomas is desperately needed. Due to their availability for immunohistochemistry testing, MIB1, survivin, securin, mitosin, EZH2, TOPOII and cyclin B1 appear to represent promising markers of clinical behavior. We realize the small number of cases included in this study; however, our study represents an important substrate for additional studies in order to identify markers helpful in predicting the behavior of ependymomas and therefore establish novel management guidelines. As indicated above, it appears that there is some overlap between certain genes in glioblastoma and ependymoma. This particular observation seems very promising in identifying those ependymomas with clinical behavior that defies their histomorphological features (ependymomas that behave aggressively while displaying limited atypical histological features). This observation is currently under additional investigations by our group.

\section{Acknowledgement}

This work was supported in part by the National Institutes of Health (grant RO1HL35716) and the Harvard Medical School (funds from the Wolbach Chair).

We regret the untimely death of Dr. Tucker Collins, M.D., Ph.D., on June 8,2007 . He was a great mentor and friend. His enthusiasm and support will be greatly missed. 


\section{References}

1 Bouffet E, Perilongo G, Canete A, Massimino M (1998) Intracranial ependymomas in children: a critical review of prognostic factors and a plea for cooperation. Med Pediatr Oncol 30: 319-329.

2 Ries L, Hankey B (1994) SEER cancer statistics review, 1973-1991: tables and graphs. National Cancer Institute, Bethesda.

3 Ho DM, Hsu CY, Wong TT, Chiang H (2001) A clinicopathologic study of 81 patients with ependymomas and proposal of diagnostic criteria for anaplastic ependymoma. J Neurooncol 54: 77-85.

4 Akyuz C, Emir S, Akalan N, Soylemezoglu F, Kutluk T, et al. (2000) Intracranial ependymomas in childhood - a retrospective review of sixty-two children. Acta Oncol 39: 97-100.

5 Korshunov A, Golanov A, Sycheva R, Timirgaz V (2004) The histologic grade is a main prognostic factor for patients with intracranial ependymomas treated in the microneurosurgical era: an analysis of 258 patients. Cancer 100: 1230-1237.

6 Merchant TE, Jenkins JJ, Burger PC, Sanford RA, Sherwood SH, et al. (2002) Influence of tumor grade on time to progression after irradiation for localized ependymoma in children. Int J Radiat Oncol Biol Phys 53: 52-57.

7 Mork SJ, Loken AC (1977) Ependymoma: a follow-up study of 101 cases. Cancer 40: 907-915.

8 Gerdes J, Becker MH, Key G, Cattoretti G (1992) Immunohistological detection of tumour growth fraction (Ki-67 antigen) in formalin-fixed and routinely processed tissues. J Pathol 168: 85-86.

9 Duffner PK, Krischer JP, Sanford RA, Horowitz ME, Burger PC, et al. (1998) Prognostic factors in infants and very young children with intracranial ependymomas. Pediatr Neurosurg 28: 215-222.

10 Figarella-Branger D, Civatte M, Bouvier-Labit C, Gouvernet J, Gambarelli D, et al. (2000) Prognostic factors in intracranial ependymomas in children. J Neurosurg 93: 605-613.

11 Horn B, Heideman R, Geyer R, Pollack I, Packer R, et al. (1999) A multi-institutional retrospective study of intracranial ependymoma in children: identification of risk factors. J Pediatr Hematol Oncol 21: 203-211.

12 Paulino AC, Wen BC, Buatti JM, Hussey DH, Zhen WK, et al. (2002) Intracranial ependymomas: an analysis of prognostic factors and patterns of failure. Am J Clin Oncol 25: 117-122.

13 Pollack IF, Gerszten PC, Martinez AJ, Lo KH, Shultz B, et al. (1995) Intracranial ependymomas of childhood: long-term outcome and prognostic factors. Neurosurgery 37: 655-666.

14 Robertson PL, Zeltzer PM, Boyett JM, Rorke LB, Allen JC, et al. (1998) Survival and prognostic factors following radiation therapy and chemotherapy for ependymomas in children: a report of the Children's Cancer Group. J Neurosurg 88: 695-703.

15 Guyotat J, Signorelli F, Desme S, Frappaz D, Madarassy G, et al. (2002) Intracranial ependymomas in adult patients: analyses of prognostic factors. J Neurooncol 60: 255-268.

16 Schild SE, Nisi K, Scheithauer BW, Wong WW, Lyons MK, et al. (1998) The results of radiotherapy for ependymomas: the Mayo Clinic experience. Int J Radiat Oncol Biol Phys 42: 953-958.

17 Marks JE, Adler SJ (1982) A comparative study of ependymomas by site of origin. Int J Radiat Oncol Biol Phys 8: 37-43.
18 Kovalic JJ, Flaris N, Grigsby PW, Pirkowski M, Simpson JR, et al. (1993) Intracranial ependymoma long term outcome, patterns of failure. J Neurooncol 15: 125-131.

19 Peschel RE, Kapp DS, Cardinale F, Manuelidis EE (1983) Ependymomas of the spinal cord. Int J Radiat Oncol Biol Phys 9: 1093-1096.

20 Taylor MD, Poppleton H, Fuller C, Su X, Liu Y, et al. (2005) Radial glia cells are candidate stem cells of ependymoma. Cancer Cell 8: 323335.

21 Modena P, Lualdi E, Facchinetti F, Veltman J, Reid JF, et al. (2006) Identification of tumor-specific molecular signatures in intracranial ependymoma and association with clinical characteristics. J Clin Oncol 24: 5223-5233.

22 Kanehisa M, Goto S, Kawashima S, Okuno Y, Hattori M (2004) The KEGG resource for deciphering the genome. Nucleic Acids Res 32 D277-280.

23 Doniger SW, Salomonis N, Dahlquist KD, Vranizan K, Lawlor SC, et al. (2003) MAPPFinder: Using Gene Ontology and GenMAPP to create a global gene-expression profile from microarray data. Genome Biol 4: R7.

24 Cho KS, Oh HY, Lee EJ, Hong SJ (2007) Identification of enhancer of zeste homolog 2 expression in peripheral circulating tumor cells in metastatic prostate cancer patients: a preliminary study. Yonsei Med J 48: 1009-1014.

25 Nakabayashi H, Hara M, Shimizu K (2006) Prognostic significance of CDC25B expression in gliomas. J Clin Pathol 59: 725-728.

26 Miyata H, Doki Y, Yamamoto H, Kishi K, Takemoto H, et al. (2001) Overexpression of CDC25B overrides radiation-induced G2-M arrest and results in increased apoptosis in esophageal cancer cells. Cancer Res 61: 3188-3193.

27 Meraldi P, Sorger PK (2005) A dual role for Bub1 in the spindle checkpoint and chromosome congression. Embo J 24: 1621-1633.

28 Wang H, Hu X, Ding X, Dou Z, Yang Z, et al. (2004) Human Zwint-1 specifies localization of Zeste White 10 to kinetochores and is essential for mitotic checkpoint signaling. J Biol Chem 279: 5459054598.

29 Obuse C, Iwasaki O, Kiyomitsu T, Goshima G, Toyoda Y, et al. (2004) A conserved Mis12 centromere complex is linked to heterochromatic HP1 and outer kinetochore protein Zwint-1. Nat Cell Biol 6: 11351141.

30 Zou H, McGarry TJ, Bernal T, Kirschner MW (1999) Identification of a vertebrate sister-chromatid separation inhibitor involved in transformation and tumorigenesis. Science 285: 418-422.

31 Fabbro M, Zhou BB, Takahashi M, Sarcevic B, Lal P, et al. (2005) Cdk1/ Erk2- and Plk1-dependent phosphorylation of a centrosome protein, Cep55, is required for its recruitment to midbody and cytokinesis. Dev Cell 9: 477-488.

32 Horvath S, Zhang B, Carlson M, Lu KV, Zhu S, et al. (2006) Analysis of oncogenic signaling networks in glioblastoma identifies ASPM as a molecular target. Proc Natl Acad Sci USA 103: 17402-17407.

33 Hirano T (2005) Condensins: organizing and segregating the genome. Curr Biol 15: R265-275.

34 Losada A, Hirano T (2005) Dynamic molecular linkers of the genome: the first decade of SMC proteins. Genes Dev 19: 1269-1287. 